\title{
Estudo de impacto ambiental e discricionariedade administrativa: a usina hidrelétrica de Mauá ${ }^{1}$
}

\author{
Ariane Maria Hasemann ${ }^{2}$
}

\begin{abstract}
Resumo
Verifica e compara os posicionamentos doutrinários sobre a existência de discricionariedade ou vinculação do Poder Público com relação ao resultado do Estudo de Impacto Ambiental quando este é exigível no âmbito do licenciamento ambiental. Conclui-se pela existência de discricionariedade administrativa em relação à concessão das licenças ambientais, demonstrando-se que ela se faz presente na lei para garantir decisões justas e corretas nos casos concretos, que coloquem em prática o significado da expressão desenvolvimento sustentável.
\end{abstract}

Palavras-Chave: Direito Constitucional; Direito Ambiental; Direito Administrativo.

\section{Introdução}

O objetivo do presente estudo é tratar da existência (ou não) de discricionariedade da Administração Pública com relação à conclusão do Estudo de Impacto Ambiental, quando este é exigível pelo ordenamento jurídico brasileiro.

Para tanto, analisar-se-á a maneira pela qual o ordenamento jurídico prevê meios para compatibilizar o desenvolvimento econômico e social e a preservação do meio ambiente, já que a Constituição Federal determina, no artigo 170, inciso VI, que a ordem econômica deve ter em conta a defesa do meio ambiente, assegurando a todos uma existência digna, e 0 artigo 225 estabelece que todos têm direito ao meio ambiente ecologicamente equilibrado.

Como subsídio ao ensaio, selecionou-se o caso da Usina Hidrelétrica de Mauá, acompanhado assiduamente pela mídia, no qual é evidente o debate sobre a prevalência dos direitos supramencionados.

Entre os instrumentos previstos pela legislação para conciliar tais interesses, encontram-se o Licenciamento Ambiental e o Estudo de Impacto Ambiental e seu respectivo

1 Este ensaio teve por referência Trabalho de Conclusão de Curso apresentado ao Curso de Direito da Universidade Estadual de Londrina, realizado sob orientação do Prof. Giovanne H. B. Schiavon.

2 Aluna do 5o ano de Direito da Universidade Estadual de Londrina. E-mail: jc_ariane@yahoo.com.br

Revista de Direito Público, LondRINA, V. 3, N. 1, P. 105-127, M Al/ AGO. 2008. 
Relatório de Impacto Ambiental (EIA/RIMA), que compõe uma das etapas do licenciamento ambiental quando da necessidade de instalação de obra ou atividade potencialmente causadora de significativa degradação do meio ambiente (art. $225, \S 1^{\circ}$, IV da CF/88).

Considerando que o EIA/RIMA visa principalmente a orientar a decisão da Administração Pública em licenciar ou não a obra ou atividade, a discussão a respeito da compatibilização entre desenvolvimento econômico e social e preservação do meio ambiente torna-se mais delineada na cizânia doutrinária sobre a existência ou não de discricionariedade do órgão ambiental em relação ao resultado do EIA/RIMA, tema central deste ensaio.

\section{A usina hidrelétrica de Mauá}

Em agosto de 2006, o Ministério Público Federal entendeu por bem propor uma ação civil pública, combinada com ação por ato de improbidade administrativa, para submeter à apreciação do Poder Judiciário o licenciamento ambiental da Usina Hidrelétrica de Mauá, tendo em vista fatos apurados em procedimento administrativo instaurado na Procuradoria da República em Londrina - Paraná.

Baseando-se em pareceres técnicos que analisam a Bacia do Tibagi, produzidos por profissionais de diversas áreas de conhecimento, o Parquet entendeu que o Estudo de Impacto Ambiental e seu Relatório de Impacto Ambiental (EIA/RIMA), elaborado pela CNEC Engenharia S.A., possui inúmeras falhas e omissões, o que tornaria o estudo inapto ao fim a que se destina, qual seja, o diagnóstico/prognóstico dos possíveis impactos ambientais gerados caso o empreendimento venha a se efetivar.

Ademais, o Ministério Público Federal aduziu que o Instituto Ambiental do Paraná (IAP), órgão perante o qual tramita o licenciamento ambiental em tela, estaria comprometido com a efetivação do empreendimento, conduzindo o procedimento de licenciamento ambiental de maneira inadequada, com inversão de seus atos, o que culminou na expedição da Licença Prévia n. 9589, com 70 (setenta) condicionantes, ao invés de serem exigidos estudos complementares.

Atualmente, a ação tramita perante a $1^{\text {a }}$ Vara Federal de Londrina/PR sob $0 n^{0}$. 2006.70.01.004036-9, e ainda não houve pronunciamento definitivo da Justiça nos autos. 
Pelo exposto, pode-se afirmar que a ação proposta pelo M PF suscita a questão de quais são os parâmetros para o exercício da discricionariedade por parte da Administração Pública quando da decisão a respeito do licenciamento ambiental. Neste sentido, o texto segue com o conceito doutrinário de discricionariedade.

\section{Discricionariedade administrativa: conceito e controle judicial}

É cediço que o princípio da legalidade norteia a Administração. Sobre o tema, afirma Celso Antônio Bandeira de Mello (2006, p. 904) que "para a legitimidade de um ato administrativo é insuficiente o fato de ser ofensivo à lei. Cumpre que seja praticado com embasamento em alguma norma permissiva que lhe sirva de supedâneo".

A discricionariedade está presente quando resta certa margem de liberdade ao administrador para optar pela melhor alternativa, segundo o interesse público, dentre aquelas prescritas pela lei (MELLO, 2006). A escolha por determinado comportamento, nos dizeres de Diógenes Gasparini (2004, p. 94, grifo do autor):

[...] se faz por critério de conveniência e oportunidade, ou seja, de mérito. Há conveniência sempre que 0 ato interessa, convém ou satisfaz ao interesse público. Há oportunidade quando o ato é praticado no momento adequado à satisfação do interesse público.

A vinculação ocorre quando a lei não concede qualquer margem de liberdade para a Administração Pública, definindo detalhadamente o modo de ação e decisão do administrador. Neste sentido, nos atos administrativos vinculados, a lei "prescreve, em princípio, se, quando e como deve a Administração Pública agir ou decidir. A vontade da lei só estará satisfeita com esse comportamento, já que não permite à Administração Pública qualquer outro" (GASPARINI, 2004, p. 93, grifo do autor).

Importante ressaltar, ainda, que não há ato inteiramente discricionário nem ato totalmente vinculado, posto que todo ato administrativo é vinculado com relação ao seu fim, que deve ser público, e também com relação ao sujeito competente para a prática do ato, que será sempre o mencionado na lei. Por outro lado, 0 ato vinculado pode ser discricionário em algum de seus aspectos, como, por exemplo, o momento de sua edição (GASPARINI, 2004). 
Di Pietro (2004) acrescenta que a discricionariedade é encontrada comumente no motivo e no conteúdo do ato. Para a autora (2004, p. 208):

0 motivo será discricionário quando: 1 . a lei não 0 definir, deixando-0 ao inteiro critério da Administração [...]; 2. a lei define o motivo utilizando noções vagas, vocábulos plurissignificativos, os chamados conceitos jurídicos indeterminados, que deixam à Administração a possibilidade de apreciação segundo critérios de oportunidade e conveniência [...].

Em se tratando de conceitos jurídicos indeterminados, há autores que afirmam que a Administração apenas tem de interpretá-los, o que não conferiria discricionariedade porque a interpretação levaria a uma única solução. No entanto, a corrente dominante no direito brasileiro afirma que se tais conceitos forem de valor, exigindo-se apreciação subjetiva do administrador, ter-se-á discricionariedade (DI PIETRO, 2004).

Com relação ao conteúdo, haverá discricionariedade "quando houver vários objetos possíveis para atingir o mesmo fim, sendo todos eles válidos perante o direito" (DI PIETRO, 2004, p. 209), como acontece quando a lei prevê, para a mesma infração, pena de suspensão ou de multa.

Ademais, insta indicar que a discricionariedade não se confunde com arbitrariedade, que é atuação ilegal, contrária à lei, enquanto a primeira é uma liberdade concedida pela própria lei e nos limites dela, como ressaltam Marcelo Alexandrino e Vicente Paulo (2007).

Vencida a distinção entre atos administrativos discricionários e vinculados, cumpre elucidar quais efeitos a matéria produz no tocante ao controle judicial dos atos administrativos.

Sendo 0 ato vinculado, não há qualquer restrição ao controle exercido pelo Poder Judiciário, pois todos os elementos que compõem 0 ato estão definidos em lei (ALEXANDRINO; PAULO, 2007).

Já em relação aos atos discricionários, a doutrina tradicional costuma afirmar que ao Poder Judiciário é vedado qualquer controle de mérito (oportunidade e conveniência) sobre os atos administrativos discricionários, pois o legislador concedeu previamente à Administração Publica um espaço para livre decisão, cabendo ao Judiciário apenas analisar a legalidade do ato (ASSUNÇÃO, 2006). 
No entanto, a doutrina e a jurisprudência modernas estão modificando este entendimento, por ser inegável que conveniência e oportunidade também se sujeitam à legalidade lato sensu. Desta feita, estando a Administração Pública submetida ao império da lei e, sendo a jurisdição inerente ao Poder Judiciário, compete a ele verificar se a Administração Pública atuou em consonância com os princípios constitucionais estabelecidos no caput do artigo $37 \mathrm{da} \mathrm{CF/88} \mathrm{em} \mathrm{sua} \mathrm{decisão} \mathrm{no} \mathrm{caso} \mathrm{concreto,} \mathrm{sem} \mathrm{que} \mathrm{isto}$ importe em violação à separação de poderes, pois as funções estatais são independentes, mas não podem ser concebidas de forma estanque (ASSUNÇÃO, 2006).

Ora, quando se tem em mente os princípios basilares do Direito Administrativo, entre eles, a razoabilidade, a proporcionalidade, a legalidade e a moralidade, e que os motivos que levam 0 administrador a decidir por determinada alternativa devem obedecer aos referidos princípios e à finalidade estabelecida em lei, é cediço que a motivação é parâmetro para o controle dos atos administrativos pelo Judiciário, sendo que seu desvirtuamento configura ilegalidade e enseja a invalidação do ato (ASSUNÇÃO, 2006).

Ademais, deve restar esclarecido que se o Poder Público atuou em conformidade com os princípios constitucionais a ele inerentes e dentro dos limites legais na escolha do que considera a melhor alternativa entre as propostas, diante do interesse público, o Poder Judiciário não poderá invalidar a decisão do administrador alegando que a solução não era a mais interessante com vistas ao interesse da coletividade, sob pena invasão ao mérito administrativo (ALEXANDRINO; PAULO, 2007).

Em matéria ambiental, é freqüente a presença de conceitos jurídicos indeterminados, que concedem discricionariedade ao administrador público em determinar 0 alcance de determinadas expressões, como também a discricionariedade se faz presente sob a justificativa de propiciar maior eficiência à Administração Pública, por ser impraticável ao legislador prever todos os casos concretos, como afirma Krell (2004).

Desta feita, o fato de o Poder Judiciário estar admitindo a possibilidade de controle dos atos discricionários por meio da motivação é de fundamental importância para garantir maior eficácia ao Direito Ambiental. 


\section{Licenciamento ambiental}

Natureza jurídica

A CF/88 determina que o meio ambiente é bem de uso comum do povo, cuja proteção e defesa incumbe tanto ao Poder Público quanto à coletividade, sendo que ao Poder Público compete uma série de providências, o que o caracteriza como gestor do direito ao meio ambiente sadio (M ILARÉ, 2007).

Ademais, como ressalta Machado (2005), esse controle das atividades econômicas que a Administração Pública faz, no sentido de buscar o desenvolvimento sustentável, só pode ser autorizado/instituído por lei, com vistas à diç̧ão do artigo 170, parágrafo único da $\mathrm{CF} / 88$.

A legislação brasileira, notadamente a Política Nacional do Meio Ambiente (Lei $\mathrm{n}^{\circ}$. 6.938/81 - artigo 9o), conferiu ao Poder Público os mais variados instrumentos para implementar sua função constitucional, entre eles o licenciamento ambiental, classificado como uma espécie de controle preventivo (M ILARÉ, 2007).

A definição de licenciamento ambiental encontra-se no artigo 1 , inciso I da Resolução CONAMA n² 237/97, in verbis:

[...] procedimento administrativo pelo qual o órgão ambiental competente licencia a localização, instalação, ampliação e a operação de empreendimentos e atividades utilizadoras de recursos ambientais, consideradas efetiva ou potencialmente poluidoras ou daquelas que, sob qualquer forma, possam causar degradação ambiental, considerando as disposições legais e regulamentares e as normas técnicas aplicáveis ao caso (BRASIL, 1997, art. 1ํ).

Ainda sobre a definição de licenciamento ambiental, Milaré (2007, p. 406) destaca que este é:

[...] ato uno, de caráter complexo, em cujas etapas podem intervir vários agentes dos diversos órgãos do SISNAMA, e que deverá ser precedido de estudos técnicos que subsidiem sua análise, inclusive de EIA/RIMA, sempre que constatada a significância do impacto ambiental.

Fiorillo (2006, p. 82), por sua vez, afirma que o licenciamento ambiental é "um encadeamento de atos administrativos, o que Ihe atribui a condição de procedimento administrativo". 
Para melhor compreensão da natureza jurídica do instituto em tela, bem como da cisão doutrinária existente a este respeito, há necessidade de relembrar a conceituação de licença e autorização advindas do Direito Administrativo.

Alexandrino e Paulo (2007) asseveram que licença é ato administrativo vinculado e definitivo, ou seja, preenchidas as condições legais, o particular tem direito subjetivo à sua obtenção, sendo que a Administração não pode revogar a licença enquanto cumpridas referidas exigências.

Para os mesmos autores supramencionados, autorização é ato discricionário e precário. Em outras palavras, à Administração cabe valorar quanto à oportunidade e conveniência de concedê-la, não existindo direito subjetivo do particular nem mesmo a sua continuidade, se deferida, posto que a Administração pode revogá-la a qualquer tempo com base na predominância do interesse público.

Diante do exposto, e tendo em vista que, além de no âmbito ambiental as normas possuírem conteúdo muito genérico, o que torna praticamente impossível o preenchimento de todos os requisitos legais e abre campo para juízo de conveniência e oportunidade do administrador, o legislador concedeu caráter precário (não definitivo) às licenças ambientais, como se infere da leitura dos artigos $10, \S 1^{\circ}$ da Lei $n^{\circ} 6.938 / 81$ e 18 da Resolução CONAM A $n^{\circ}$ 237/97, há doutrinadores que defendem a tese de que a licença ambiental seria verdadeira autorização administrativa (M ILARÉ, 2007). Entre os doutrinadores que partilham da conclusão acima exposta está Machado (2005), que fundamenta seu entendimento no vocábulo "autorização", utilizado no parágrafo único do artigo 170 do texto constitucional.

Posicionamento contrário relevante vem a ser o de Milaré (2007), para quem há equívoco em tentar ajustar a licença ambiental nos moldes da licença administrativa, na medida em que os princípios que regem os dois ramos do Direito a elas inerentes nem sempre coexistem de forma harmônica.

Para elucidar seu entendimento, 0 autor explicita que, modernamente, não se pode conceber discricionariedade e vinculação de forma estanque, pois os atos administrativos não são inteiramente vinculados ou discricionários. Desta feita, o eminente jurista assevera que: 
No caso do licenciamento ambiental, sem negar à Administração a faculdade de juízos de valor sobre a compatibilidade do empreendimento ou atividade a planos e programas de governo, sobre vantagens e desvantagens para o meio considerado, etc., importa enfatizar que o matiz que sobressai aquele que lhe dá colorido especial, é 0 da subordinação da manifestação administrativa ao requerimento do interessado, uma vez atendidos, é claro, os pressupostos legais [...] (MILARÈ, 2007, p. 410, grifo do autor).

Além disso, entende Milaré (2007) que o prazo de validade das licenças, estipulado no artigo 18 da Resolução CONAMA $n^{\circ} 237 / 97$, bem como a renovabilidade das mesmas (artigo $10 \S 1^{\circ}$ da Lei $n^{\circ}$ 6.938/81) não retiram 0 caráter de estabilidade da licença ambiental, por não existir, in casu, suspensão por mera discricionariedade do administrador. Neste sentido, a licença ambiental seria detentora de:

[...] uma estabilidade temporal, que não se confunde com a precariedade das autorizações, nem com a definitividade das licenças tradicionais. Garante-se, numa palavra, no lapso temporal da licença, a inalterabilidade das regras impostas no momento da outorga, salvo, é claro, se o interesse público recomendar o contrário, quando, então, em benefício da sociedade, poderá 0 ato ser revisto (MILARÉ, 2007, p. 411, grifo do autor).

A título complementar, o artigo 19 da Resolução CONAMA n 237/97 arrola as hipóteses em que pode haver revisão da licença ambiental concedida, uma vez que a estabilidade temporal não se confunde com direito adquirido (MILARÉ, 2007).

Isto posto, importante notar que, a despeito da discrepância doutrinária com relação à natureza jurídica da licença ambiental, os autores são praticamente uníssonos ao afirmar que há certa margem decisória conferida ao administrador na concessão das licenças, cujo alcance e limitações serão abordados à frente, no discorrer do objeto central deste estudo.

Etapas do licenciamento ambiental

As fases que compõem o licenciamento ambiental, o qual, nos termos do artigo $2^{\circ}$ da Resolução n²37/97, será exigido para empreendimentos e atividades utilizadores de recursos ambientais efetiva ou potencialmente poluidores ou passíveis de causar degradação ambiental, estão definidas no artigo 10 da mesma Resolução. 
Especificamente à etapa do licenciamento que diz respeito ao deferimento da licença (inciso VIII), é necessário frisar que esta se desdobra na expedição de três licenças, descritas no artigo $8^{\circ}$ da Resolução em tela:

I - Licença Prévia (LP) - concedida na fase preliminar do planejamento do empreendimento ou atividade aprovando sua localização e concepção, atestando a viabilidade ambiental e estabelecendo os requisitos básicos e condicionantes a serem atendidos nas próximas fases de sua implementação;

II - Licença de Instalação (LI) - autoriza a instalação do empreendimento ou atividade de acordo com as especificações constantes dos planos, programas e projetos aprovados, incluindo as medidas de controle ambiental e demais condicionantes, da qual constituem motivo determinante;

III - Licença de Operação (LO) - autoriza a operação da atividade ou empreendimento, após a verificação do efetivo cumprimento do que consta das licenças anteriores, com as medidas de controle ambiental e condicionantes determinados para a operação.

Parágrafo único - As licenças ambientais poderão ser expedidas isolada ou sucessivamente, de acordo com a natureza, características e fase do empreendimento ou atividade. (BRASIL, 1997, art. 8o).

Conforme assevera Machado (2005), o atestado de "viabilidade ambiental" do empreendimento (inciso I), no caso de atividades que podem causar significativa degradação do ambiente, deve ser conjugado com a realização de EIA/RIMA, sendo que, de acordo com 0 inciso VII do artigo $2^{\circ}$ da Resolução CONAM A $n^{\circ}$. 01/86, o licenciamento de barragens com fins hidrelétricos acima de $10 \mathrm{MW}$ depende de elaboração de EIA/RIM A.

Os estudos correrão às expensas do empreendedor e deverão ser realizados por profissionais legalmente habilitados, os quais serão responsáveis pelas informações prestadas nas esferas administrativa, civil e penal (artigo 11 da Resolução n. 237/97). 0 custo da análise para obtenção da licença, realizado pelo órgão ambiental, será ressarcido pelo empreendedor (artigo 13 da Resolução n. 237/97).

Com relação à competência, observa-se que as três esferas de governo estão aptas a licenciar, em consonância com o disposto no artigo 23, inciso VI da CF/88. A Resolução CONAMA $n^{\circ}$. 237/97, nos artigos $4^{\circ}$ a $7^{\circ}$, procura estabelecer critérios para que 0 licenciamento ambiental seja realizado em um único nível de competência, o que tanto Fiorillo (2006) quanto Milaré (2007) consideram ferir a competência comum material conferida aos entes pela Carta Magna.

Milaré (2007) ressalta que as Resoluções CONAMA $n^{\circ}$. 237/97, bem como a $n^{\circ}$. 01/86, que será estudada adiante, estabelecem o procedimento geral para o licenciamento 
ambiental, de modo que há resoluções do CONAMA específicas para algumas atividades, expedidas na busca pela devida proteção ambiental que o licenciamento deve conferir.

Finalmente, frise-se que a publicidade acompanha o procedimento de licenciamento ambiental "desde o requerimento da licença até a sua outorga, rejeição ou renovação" (MILARÉ, 2007, p. 431), como se observa da conjugação das disposições da Resolução $n^{\circ}$. 237/97, da Resolução n. 01/86 e da própria Lei $n^{\circ}$. 6.938/81, em seu artigo 10, $\S 1^{\circ}$ (MILARÉ, 2007).

\section{Estudo de impacto ambiental e relatório de impacto ambiental - EIA/ RIMA}

Noções propedêuticas

A avaliação de impactos ambientais (AIA) também é um dos instrumentos de gestão ambiental, instituído pela Política Nacional do M eio Ambiente - Lei n. 6.938/81 - artigo 9o, inciso III, a qual deve ser conjugada com o licenciamento ambiental quando a atividade ou obra for passível de gerar significativa degradação ao meio ambiente (MILARÉ, 2007).

O Estudo de Impacto Ambiental (EIA) pode ser considerado uma das vertentes da AIA, mas com ela não deve ser confundido, uma vez que a AIA é muito mais ampla que o EIA, contemplando tanto ações concretas quanto programáticas, denominadas, no último caso, de Avaliações Ambientais Estratégicas (M ILARÉ, 2007).

A matéria está regulamentada basicamente pelas Resoluções CONAM A n. 01/86 e $n^{\circ}$. 09/87, sem olvidar da importância da Resolução $n^{\circ}$. 237/97, anteriormente tratada com mais profundidade, e da disposição contida no artigo 225, § $1^{\circ}$, inciso IV da CF/88.

Milaré (2007) frisa que o ElA é uma das mais importantes espécies de "estudos ambientais" (conforme conceitua a Resolução $n^{\circ}$. 237/97, artigo $1^{\circ}$, inciso III), sendo exigível apenas nos casos de significativa degradação ambiental, a qual, segundo o autor, é presumível, salvo prova em contrário, para as atividades mencionadas no artigo $2^{\circ} \mathrm{da}$ Resolução $n^{\circ}$. 01/86, entre elas as hidrelétricas acima de $10 \mathrm{MW}$ (inciso VII).

Fernandes (2005, pp. 63-64) destaca que:

[...] 0 instituto tem por escopo máximo a avaliação, em termos proporcionais, das alterações eventuais que um empreendimento, tanto público quanto privado, pode ocasionar ao meio ambiente, possuindo caráter nitidamente preventivo. 
E, justamente por possuir caráter preventivo, o EIA deve ser elaborado previamente à decisão administrativa de outorga licença para implementar a atividade ou obra, sendo que sua não-elaboração acarreta sanções de ordem penal, civil e administrativa tanto para quem tinha por dever exigi-lo (ou seja, o Poder Público) quanto para aquele que deveria elaborá-Io (MILARÉ, 2007).

Sobre o tema, Benjamin (1992) ressalta que o EIA é normalmente produzido antes da concessão da licença, inclusive no caso de licença prévia, uma vez que seu objetivo principal assenta-se em contribuir para a formação do mérito da decisão administrativa.

Frise-se que to do EIA tem por conseqüência a produção de um Relatório de Impacto Ambiental - RIMA (artigo $9^{\circ}$ da Resolução $n^{\circ}$. 01/86), o qual tem por finalidade tornar a linguagem do EIA acessível ao público (FIORILLO, 2006). Neste sentido:

0 Relatório de Impacto Ambiental, destinando-se especificamente ao esclarecimento das vantagens e conseqüências ambientais do empreendimento, refletirá as conclusões daquele [EIA]. (MILARÉ, 2007, p. 363).

Com relação aos empreendimentos passíveis de ocasionar significativa degradação ao meio ambiente, os quais ensejam a prévia elaboração de EIA, conforme acima exposto, a doutrina, diante da dificuldade de se precisar o conceito de significativa degradação (o qual pode ser considerado como um conceito jurídico indeterminado), é praticamente uníssona em afirmar que as hipóteses constantes do artigo $2^{\circ}$ da Resolução $n^{\circ}$. 01/86 são regidas pelo princípio da obrigatoriedade, ou seja, a Administração Pública deve exigir a elaboração do EIA naqueles casos (FERNANDES, 2005). Assim, considera-se que o rol:

[...] é meramente exemplificativo no sentido de somatória de atividades, mas considerado obrigatório para as relacionadas. Nesses casos o Poder Público está vinculado, não podendo apresentar razões de dispensa do estudo e respectivo relatório, sob pena de incorrer na prática de crime de prevaricação, além da responsabilidade civil e administrativa do agente público envolvido. (FERNANDES, 2005, p. 94).

Milaré (2007) afirma, baseando-se no teor do parágrafo único do artigo $3^{\circ}$ da Resolução n०. 237/97, que a presunção de gravidade de impacto das atividades e obras 
constantes do rol do artigo $2^{\circ}$ da Resolução $n^{\circ}$. 01/86 é juris tantum, ou seja, comporta prova em contrário, produzida pelo empreendedor.

Contrariamente, Benjamin (1992) acredita que o rol do artigo 2ํ da Resolução nº. 01/86 gera presunção absoluta da necessidade de elaboração do EIA/RIMA, com total vinculação do administrador. Às hipóteses não previstas no rol do artigo retrocitado, restaria certa margem de discricionariedade na apreciação do órgão competente.

Cabe ao proponente do projeto elaborar o que Fiorillo (2006) denomina como Relatório de Impacto Ambiental (RAIAS), o qual deve ser levado à apreciação do órgão ambiental competente para que este possa determinar se há ou não necessidade de elaboração do EIA, por meio de decisão fundamentada no último caso. O RAIAS deve ser redigido por técnicos habilitados e possuir o conteúdo básico do ElA.

Assim, caso seja adotado o entendimento de Milaré (2007), ou seja, que há presunção relativa, o proponente elabora o RAIAS para elidi-la. Caso seja adotado 0 posicionamento de Benjamin (1992), para as atividades não constantes do rol do artigo 2ํo é interessante a elaboração do RAIAS para subsidiar o entendimento do órgão licenciador.

Desta feita, ensina Milaré (2007, p. 374, grifo do autor):

[...] é possível concluir que o órgão de controle mantém certa dose de liberdade para avaliar dito pressuposto do EIA/RIMA, isto é, o significativo impacto ambiental. Evidenciada, porém, por regular prova técnica, a insignificância do impacto, torna-se inviável a exigência do estudo.

Ressalte-se, igualmente, que se houver significância no impacto, a exigência do EIA foge à discricionariedade do órgão estadual licenciador (BENJAM IN, 1992).

Ato contínuo, como leciona Fernandes (2005), a partir do momento em que o órgão competente define que deve ser realizado um EIA, devido às características da atividade ou obra, é imprescindível a elaboração de um Termo de Referência - TR, o que geralmente é feito pelo próprio Poder Público. O TR será baseado no RAIAS, o qual é denominado por Fernandes (2005) como Relatório Ambiental Preliminar, e tem por objetivo orientar a produção de qualquer estudo ambiental, no caso, o EIA/RIM A.

Em se tratando de competência para exigir a feitura do ElA, extrai-se da leitura da Resolução $n^{\circ}$. 01/86 que a iniciativa foi entregue ao órgão estadual competente, exceto nos 
casos de alçada do IBAMA e do Município (interesse exclusivamente local), interpretação esta que coaduna com o exposto na Resolução n. 237/97 (MILARÉ, 2007).

Importante frisar também que a produção do ElA, devido a sua abrangência e complexidade, cabe a uma equipe multidisciplinar habilitada, conforme dicção do artigo 11 da Resolução n. 237/97, a qual será contratada pelo proponente do projeto - artigo $8^{\circ}$ da Resolução $n^{\circ}$. 01/86, que deverá acompanhar todas as fases do estudo, a fim de facilitar a identificação de problemas e soluções viáveis (FERNANDES, 2005). A habilitação da equipe decorre da inscrição de seus membros no Cadastro Técnico Federal administrado pelo IBAM A (MILARÉ, 2007).

Destaque-se que, caso haja divergência entre os membros da equipe, a mesma deverá constar do RIM A, para posterior análise do órgão ambiental (MILARÉ, 2007).

Merece destaque também o disposto no parágrafo único do artigo 11 da Resolução $n^{\circ}$. 237/97, o qual sujeita tanto 0 empreendedor quanto a equipe multidisciplinar a sanções administrativas, civis e penais pelas informações prestadas no âmbito do EIA/RIM A.

O órgão ambiental e o EIA/RIM A

Diante de todo o exposto, ensina M achado (2005) que é fundamental compreender que a realização do EIA/RIMA volta-se precipuamente a trazer elementos para subsidiar a decisão administrativa, a qual, num primeiro momento, será voltada para a concessão ou não da licença prévia, como esclarecido anteriormente.

No entanto, como afirma M achado (2005, p. 258):

0 Estudo de Impacto, contudo, não afasta o dever da Administração Pública ambiental de verificar a fundamentação desse estudo. Para acolher ou para deixar de acolher as diretrizes do EPIA o órgão ambiental deverá fundamentar sua decisão. Não se exige do órgão ambiental que faça um Estudo de Impacto paralelo ou um 'contra-estudo', mas que verifique em profundidade o Estudo de Impacto apresentado.

Retomando o tema da licença prévia, é importante destacar que esta constitui a etapa do licenciamento ambiental em que o Poder Público busca demonstrar ao proponente suas exigências, as quais se baseiam tanto no poder vinculado quanto no discricionário. 
Neste sentido, além daquilo que a lei expressamente impõe, cabe à Administração adicionar o que entender cabível diante do interesse público (M ACHADO, 2005).

Além disso, vale ressaltar que a licença prévia não vincula a Administração ao pedido, ou seja, não há direito adquirido, por parte do empreendedor, ao deferimento das etapas seguintes, sendo que qualquer decisão do órgão licenciador no sentido de acelerar o procedimento será tida como nula (MACHADO, 2005).

Finalmente, é imperioso ressaltar que o ElA pode ser considerado um ato formal, 0 qual deve seguir diretrizes gerais fixadas em lei, sob pena de invalidação. Frise-se que 0 Poder Público não pode transigir ou negociar a respeito do EIA, devido a sua feição pública, que o torna indisponível (BENJAM IN, 1992).

Feitas estas considerações, na próxima seção abordar-se-á de que maneira 0 EIA/RIM A auxilia a tomada de decisão por parte do administrador público, inclusive atuando como balizador da mesma.

\section{Estudo de impacto ambiental e discricionariedade administrativa}

A esta seção ficou reservada a análise da influência do EIA/RIMA e toda a principiologia que o cerca na tomada de decisão por parte da Administração Pública.

0 cerne do tema consiste nas seguintes questões: está o Poder Público vinculado às conclusões do EIA/RIMA ou resta ao administrador determinada margem de conveniência e oportunidade em sua decisão? Se houver discricionariedade, quais seus limites?

Diante da importância do assunto, a doutrina se divide, de modo que os posicionamentos de maior relevância serão abordados adiante, com a fundamentação necessária a cada um deles.

Primeiramente, relembre-se que incumbe ao Poder Público, precipuamente, assegurar a preservação do meio ambiente. Assim, diante da importância do meio ambiente, caracterizado como bem de uso comum do povo e essencial à qualidade de vida pela CF/88, a tendência moderna é no sentido de reduzir a autonomia do administrador em matéria ambiental, ou, ao menos, fazer com que haja consideração da variante ambiental em sua deliberação (BENJAM IN, 1992). 
Note-se que referida inclinação do legislador em restringir a liberdade da Administração na seara ambiental decorre indubitavelmente da prevalência dos instrumentos preventivos neste ramo, entre eles, o EIA (BENJAMIN, 1992).

Foi mencionado que a licença ambiental não pode ser confundida com a licença administrativa, que é ato vinculado por excelência, devido aos princípios próprios que regem o Direito Ambiental. Já se sabe, igualmente, que o EIA/RIM A é orientado a trazer elementos que auxiliem o processo decisório, devendo o estudo, pois, ser anterior à concessão de qualquer das licenças, até mesmo da licença prévia.

Para Benjamin (1992), o EIA/RIMA atua como balizador da decisão do administrador, sem, contudo, confundir-se com ela. Nas palavras do eminente doutrinador:

Sendo momento preparatório da decisão, o EIA a orienta, informa, fundamenta e restringe mas, tecnicamente falando, não a integra como um dos seus elementos internos. É parte do procedimento decisório mas não é componente interior da decisão administrativa (BENJAM IN, 1992, p. 6).

O autor supracitado lembra que, antes do ElA ser introduzido no sistema brasileiro, o administrador possuía ampla liberdade de avaliação, desde a estimativa da repercussão da obra ou atividade no meio ambiente, passando pela decisão a respeito de como e quando iria proceder à análise, até a decisão final. Assim, considera Benjamin (1992) ser evidente que 0 EIA restringiu a margem de liberdade concedida à Administração:

[...] numa perspectiva mais moderna, cabe vê-lo [o EIA] com (sic) verdadeiro freio da atividade discricionária do Estado em matéria ambiental, ao exigir uma motivação explícita ou implícita da decisão administrativa, na busca da decisão ótima em termos de proteção do meio ambiente. Foi esta [...] a concepção adotada pelo sistema brasileiro (BENJAM IN, 1992, p. 7).

Conseqüência direta da limitação da discricionariedade administrativa é a ampliação do controle judicial e social dos atos praticados pelo administrador (FERNANDES, 2005).

Ressalte-se que o EIA não anula todo e qualquer juízo de conveniência e oportunidade por parte do administrador, tendo em vista que pode haver opção por uma das alternativas propostas que não seja a que preservará mais o meio ambiente, desde que a opção seja devidamente fundamentada e razoável e tenha como base o estudo como um 
todo. Ora, não se pode perder de vista que o que se busca é o denominado desenvolvimento sustentável: sabe-se que é impensável haver crescimento econômico e social sem interferir no meio ambiente, mas a $\mathrm{CF} / 88$ procurou incutir na sociedade que deve existir um equilíbrio entre os fatores (BENJAM IN, 1992).

Pelo exposto, observa-se que, se o EIA concluir pela rejeição do projeto ou optar por uma alternativa que não seja aquela proposta pelo empreendedor, o administrador deve eleger uma entre duas saídas: ou aceita a conclusão do EIA e não licencia o projeto; ou repele o resultado do EIA e licencia o projeto. Em ambas as hipóteses deve haver motivação da decisão, para que seja possível levar efetivamente a discussão ao Poder Judiciário (BENJAMIN, 1992).

A exigência de motivação da decisão administrativa atua, pois, diretamente no aumento do controle da atividade discricionária ambiental. Diante de sua importância:

Cabe salientar, ainda, que é imprestável a motivação alicerçada em conclusões e opções vagas, bem como aquela sem suporte nos fatos aduzidos; do mesmo modo, não tem qualquer valor a motivação cientificamente indefensável explicada com terminologia incompreensível, contraditória com sua base analítica, enganosa, arrogante, insensível aos argumentos contrários, ou incompleta (BENJAM IN, 1992, p. 22).

É importante advertir novamente que, apesar do EIA/RIM A atuar como orientador da decisão administrativa, o Poder Público deve verificar a fundamentação do estudo apresentado em profundidade, o que não significa, entretanto, a elaboração de um estudo paralelo.

Nesta esteira, Benjamin (1992) afirma que a principiologia que cerca 0 licenciamento ambiental e o EIA/RIMA, como seu pressuposto, acaba por instaurar verdadeiro due process ambiental, o qual:

[...] decorre da democratização do atuar administrativo e da função social da propriedade, materializando-se na intervenção direta e obrigatória dos cidadãos interessados no iter e na decisão final; exige, ademais, um atuar administrativo neutro e não comprometido com o desfecho do procedimento licenciador (BENJAMIN, 1992, p. 26).

Benjamin (1992) adverte que o EIA/RIMA deve atuar efetivamente no processo decisório do Poder Público, não se resumindo a mera formalidade. Desta feita, a licença 
concedida contrariamente aos princípios norteadores do Direito Ambiental e do próprio ElA está sujeita à invalidação.

Fernandes (2005) posiciona-se no mesmo sentido de Benjamin (1992) e fundamenta seu entendimento ao comparar o EIA a um parecer de uma consultoria jurídica:

Ambos realizados por técnicos no assunto, apontam para uma ou mais soluções possíveis, possuem verdadeiro efeito inibidor de antijuridicidade.

Caso a Administração Pública não adote a solução por eles prescrita, assumirá, por sua conta e risco, as conseqüências de seu ato (FERNANDES, 2005, p. 120).

Já Fiorillo (2006) considera que, mesmo sendo o EIA/RIMA desfavorável, o administrador poderá conceder a licença, havendo, in casu, uma discricionariedade sui generis decorrente do próprio texto constitucional, que permite o sopeso entre a proteção ao meio ambiente e o desenvolvimento econômico. Neste sentido, 0 autor se aproxima dos posicionamentos anteriormente explicitados, ao afirmar que 0 EIA/RIMA restringe a discricionariedade do Poder Público, mas que este pode optar por conceder a licença de maneira fundamentada.

Entretanto, 0 autor entende que um EIA/RIMA favorável vincula a autoridade competente à concessão da licença, havendo, no caso, direito do empreendedor para desenvolver a atividade, pois:

[...] na medida em que o EIA/RIM A favorável condiciona a autoridade à outorga da licença ambiental, inexistem óbices para que a ordem jurídica do capitalismo esteja plenamente adaptada às necessidades de desenvolvimento da pessoa humana como valor maior protegido pelo Direito Ambiental brasileiro (FIORILLO, 2006, p. 96).

Silva (2005), por sua vez, afirma que, sendo o EIA/RIM A um estudo global de todas as conseqüências que poderão advir da implantação do empreendimento, não há como 0 administrador deixá-lo de lado ao tomar sua decisão, exceto quando o EIA/RIMA estiver falho e viciado. Aproxima-se o autor da opinião de Fiorillo (2006) ao afirmar que:

[...] uma vez estando comprovado pelo Estudo de Impacto Ambiental - ElA e pelo Relatório de Impacto Ambiental - RIMA que um determinado projeto atende às condições e aos padrões técnicos fixados em regulamento, 0 administrador público obriga-se a conceder o licenciamento, sob pena de incorrer em crime de 
prevaricação, previsto no art. 319 do Código Penal (SILVA, 2005, p. 351, grifo do autor).

Ademais, vale ressaltar que a matéria ora estudada está longe de ser pacífica. Para ilustrar a imensa gama de entendimentos e posições doutrinárias, cita-se o posicionamento controvertido de Paulo de Bessa Antunes, o qual acredita que a solução apontada no EIA/RIM A vincula o Poder Público (SILVA, 2005). Para Antunes, é ilícito negar ou aprovar o projeto por meio de elementos estranhos ao EIA/RIM A. Em suas palavras:

A vinculação existe, na medida em que a Administração Pública, deverá levar em conta, ao realizar a sua decisão pela implantação ou não do projeto, os elementos que constem do Estudo de Impacto Ambiental e do seu relatório de impacto sobre o meio ambiente (apud FERNANDES, 2005, p. 124-125).

Realça-se que o entendimento do doutrinador acima referido não é majoritário, uma vez que:

[...] por exemplo, conclusões baseadas em parâmetros ultrapassados ou desatualizados, ou ainda desconsiderando o princípio do desenvolvimento sustentado, não podem servir de limites ao bom senso e equilíbrio do administrador público que deverá, acima de tudo, cumprir os princípios e mandamentos constitucionais [...] (FERNANDES, 2005, p. 127-128).

Por fim, parece acertada a tese de que resta certa liberdade de atuação do administrador público em sede de licenciamento ambiental, atuando o EIA/RIM A e todos os princípios que o cercam como balizadores desta margem de autonomia do Poder Público.

0 entendimento se justifica quando analisado profundamente 0 texto constitucional em seu conjunto: a CF/88 propõe a integração do desenvolvimento econômico e social com a preservação ambiental. Desta feita, como bem ressalta Milaré (2007, p. 161):

0 objetivo central do Estudo de Impacto Ambiental é simples: evitar que um projeto (obra ou atividade), justificável sob o prisma econômico ou em relação aos interesses imediatos de seu proponente, revele-se posteriormente nefasto ou catastrófico para o meio ambiente.

Neste sentido, o instituto do EIA/RIMA é a expressão viva do princípio do desenvolvimento sustentável, possibilitando: "a escolha da melhor alternativa para a 
implantação de um dado projeto, com a compatibilização de todos os interesses envolvidos e que seja favorável ao meio ambiente" (FERNANDES, 2005, p. 124).

Seria impossível conceber a tese da vinculação do administrador às conclusões do EIA/RIM A no sistema brasileiro porque, sendo o Poder Público gestor do bem ambiental (a titularidade deste pertence à coletividade), cabe a ele conciliar os interesses da coletividade em cada caso concreto. 0 papel do EIA/RIMA restringe-se, tão-somente, a subsidiar a decisão administrativa.

Assim, para propiciar maior eficiência:

O legislador sempre vai conceder um grau maior de discricionariedade onde as circunstâncias da realidade, que deve ser regulamentada, dificilmente são previsíveis, e o alcance de um determinado fim exige o exercício de conhecimentos específicos da Administração para garantir uma decisão justa e correta no caso concreto (KRELL, 2004, p. 18).

Por outro lado, a discricionariedade deve manter-se dentro dos limites legais, sob pena de transformar-se em arbitrariedade, sendo que o EIA/RIMA, da maneira como foi concebido pelo ordenamento jurídico, ato formal e público, atua como mecanismo de controle da liberdade do administrador, permitindo tanto o controle judicial quanto comunitário (e até mesmo administrativo) do procedimento licenciatório ambiental.

Nesta esteira, por óbvio que o que deve ser considerado como justo e correto em sede de licenciamento ambiental é o posicionamento do administrador que compatibilize qualidade ambiental e desenvolvimento, que deve ser externado por meio de uma decisão fundamentada, razoável e transparente, resultante de um procedimento administrativo ambiental comprometido tão-somente com a realização dos ditames constitucionais e legais.

É imperativo reconhecer que a conciliação entre desenvolvimento e meio ambiente se resume a pôr em prática o significado da expressão desenvolvimento sustentável, que propõe a conciliação entre desenvolvimento e proteção ambiental, a qual é uma meta de difícil realização que, para sair do campo da utopia, exige uma série de mudanças graduais da sociedade, entre elas o desenvolvimento da consciência ecológica e da responsabilidade sócio-ambiental, além da necessidade de implementar instrumentos legais adequados ao controle da viabilidade ambiental dos projetos (MILARÉ, 2007). 
Desta feita, como destaca Milaré (2007) é necessário esforço conjunto dos governos, da comunidade e dos empresários para tornar o princípio do desenvolvimento sustentável uma realidade no Brasil e no mundo.

Não é demais frisar que a Constituição Federal de 1988 é "um dos sistemas mais abrangentes e atuais do mundo sobre a tutela do meio ambiente" (M ILARÉ, 2007, p. 147), a qual se soma uma série de regramentos infraconstitucionais, entre eles os que regulamentam o EIA/RIMA, instrumento fundamental de controle das decisões públicas e privadas relacionadas ao meio ambiente. Portanto:

É fundamental que todas as pessoas e autoridades responsáveis se lancem ao trabalho de tirar essas regras do limbo da teoria para a existência efetiva da vida real; na verdade, o maior dos problemas ambientais brasileiros é o desrespeito generalizado, impunido ou impunível, à legislação vigente (MILARÉ, 2007, p. 148).

Assim, para que os valores constitucionais a respeito do tema sejam colocados em prática no Brasil, basta que haja vontade política (BENJAM IN, 1992).

0 desenvolvimento e a preservação podem caminhar juntos, pois o aparato constitucional e legal está definido e à disposição, basta colocá-lo em prática e aprimorá-lo.

\section{Conclusão}

Este ensaio analisou os posicionamentos doutrinários acerca da existência ou não de discricionariedade do Poder Público com relação à solução apontada pelo EIA/RIMA, quando este se faz exigível pelo ordenamento brasileiro, como ocorreu no licenciamento da Usina Hidrelétrica de Mauá.

Concluiu-se pela existência de discricionariedade na tomada de decisão do administrador a respeito da concessão ou não das licenças ambientais, pois, sendo impossível ao legislador prever todas as situações, é interessante que o administrador, que possui maior proximidade com os casos concretos, possua uma margem de liberdade, dentro da lei, a fim de compatibilizar os interesses envolvidos, os quais, no caso em tela, são o desenvolvimento econômico e social e a defesa do meio ambiente, ambos previstos constitucionalmente. 
Para tornar referida conclusão mais evidente, delimitou-se o conceito de discricionariedade administrativa, com demonstração de que a tendência moderna é admitir o controle da legalidade, em sentido lato, do mérito administrativo por meio da motivação, o que interessa ao caso do licenciamento da UHE Mauá justamente por ter-se concluído pela existência de discricionariedade do administrador em licenciar e pelo fato do Ministério Público Federal ter submetido seu licenciamento ao controle judicial.

Após, descreveram-se as etapas que compõe o licenciamento, evidenciando que 0 EIA/RIMA, quando a obra ou atividade for considerada potencialmente causadora de significativos impactos ambientais, torna-se imprescindível para atestar a viabilidade ambiental necessária à concessão da licença prévia. No caso do licenciamento da UHE Mauá, - MPF entendeu que o EIA/RIMA não foi apto a diagnosticar os possíveis impactos ambientais gerados caso 0 empreendimento se efetive, motivo pelo qual o órgão ambiental competente deveria, no ponto de vista do Parquet, ter optado pela não concessão da licença prévia, exigindo do empreendedor estudos complementares.

Já na última seção que compõe este ensaio, foram estudados os diversos posicionamentos doutrinários acerca da discricionariedade ou vinculação do Poder Público àquilo apontado no EIA/RIM A. Optou-se pelo entendimento que propugna pela existência de discricionariedade do administrador, uma vez que, se devidamente respeitados os ditames impostos pelo ordenamento jurídico, a discricionariedade seria a forma mais conveniente de aproximar a decisão do administrador do interesse público, possibilitando a ponderação, no caso concreto, entre desenvolvimento econômico e social e a qualidade ambiental, constitucionalmente protegidos. Neste ponto, vale ressaltar que o MPF entendeu que os limites da discricionariedade, no licenciamento da UHE Mauá, foram ultrapassados.

Finalmente, ressalte-se que, apesar de haver muitas incertezas no campo da preservação ambiental, a tutela jurídica brasileira do meio ambiente possui princípios delineados, mesmo que ainda sujeitos melhoramentos, que devem ser colocados em prática por meio do empenho de todos no cumprimento de seus papéis sociais. Nesta esteira, sem olvidar que a decisão final a respeito da validade do licenciamento ambiental da UHE Mauá cabe ao Poder Judiciário, pode-se afirmar que o MPF, entendendo que o ordenamento jurídico foi desrespeitado, ao propor a ação civil pública combinada com a ação por ato de 
improbidade administrativa que ensejou o presente estudo, fez valer sua missão constitucional.

\section{Referências}

ALEXANDRINO, Marcelo; PAULO, Vicente. Direito administrativo descomplicado. 14. ed. Niterói: Impetus, 2007.

ASSUNÇÃO, M atheus Carneiro. O controle judicial dos atos administrativos discricionários à luz da jurisprudência do STF e do STJ. Jus Navigandi, Teresina, v. 10, n. 1078, 14 jun. 2006. Disponível em: «ttp://jus2.uol.com.br/doutrina/texto.asp?id=8508>. Acesso em: 24 maio 2008.

BENJAM IM , Antonio Herman de Vasconcellos e. Os princípios do Estudo de Impacto Ambiental como limites da discricionariedade administrativa. Revista Forense, Rio de Janeiro, n. 317, p. 25-45, jan./mar. 1992. Disponível em:

ঝttp://bdjur.stj.gov.br/dspace/handle/2011/8746>. Acesso em: 17 de set. 2007.

BRASIL.Resolução CONAM A n. 237, de 19 de dezembro de 1997. Dispõe sobre a revisão e complementação dos procedimentos e critérios utilizados para o licenciamento ambiental. Diário Oficial, Brasília, DF, n. 247, p. 30.841-30.843. 22 dez. 1997.

DI PIETRO, Maria Sylvia Zanella. Direito administrativo. 17. ed. São Paulo: Editora Atlas, 2004.

FERNANDES, Paulo Victor. Impacto ambiental: doutrina e jurisprudência. São Paulo: Revista dos Tribunais, 2005.

FIORILLO, Celso Antonio Pacheco. Curso de direito ambiental brasileiro. 7.ed. rev. e atual. São Paulo: Saraiva, 2006.

GASPARINI, Diógenes. Direito administrativo. 9. ed. São Paulo: Saraiva, 2004.

KRELL, Andreas J. discricionariedade administrativa e proteção ambiental: o controle dos conceitos jurídicos indeterminados e a competência dos órgãos ambientais - um estudo comparativo. Porto Alegre: Livraria do Advogado, 2004.

M ACHADO, Paulo Affonso Leme. Direito ambiental brasileiro. 13. ed. São Paulo: Malheiros, 2005.

MELLO, Celso Antônio Bandeira de. Curso de direito administrativo. 20. ed. São Paulo: Malheiros, 2006.

MILARÉ, Édis. Direito do ambiente: doutrina, jurisprudência, glossário. 5. ed. São Paulo: Revista dos Tribunais, 2007. 
Estudo de impacto ambiental e discricionariedade administrativa: a usina hidrelétrica de Mauá

SILVA, Américo Luís Martins. Direito do meio ambiente e dos recursos naturais. v. 1. São Paulo: Revista dos Tribunais, 2005. 